For any of this to occur, support (and pressure) also must be forthcoming from forces outside graduate schools. In particular:

- Graduate fellowship programs ought to include incentives to encourage-even require-graduate departments to attend to better preparation for teaching. Foundations and other sources of fellowship funding could and should insist on this.

- Undergraduate institutions must make evidence of preparation for teaching a much more significant factor in hiring criteria.

- Undergraduate institutions should enter into dialogue with graduate schools to make clear what they need and expect in the preparation of those who will become educators as well as scholars on their faculties.

- Finally, undergraduate institutions should be prepared to enter into partnerships with graduate schools (along the lines explored in this project) in order to facilitate the preparation of new Ph.D.s for teaching.

\section{Conclusion}

Ultimately, the agenda for reform described and supported by this report is one that demands the attention of all those concerned about the future of American higher education. If those who teach in the undergraduate classroom do not understand the processes of teaching and learning, do not care about their teaching, and do not care about the missions of their institutions and the welfare of their students, even the most elegant, appropriate, and useful curriculum will be less than fully effective. Graduate and undergradu- ate institutions, as well as foundations that provide support for the education of new Ph.D.s, must cooperate to bring about effective reform in the preparation of graduate students for the professional responsibilities of college teachers.

The challenges facing the next generation of the professoriat - to be able to teach effectively and meet the developmental needs of their students - will be greater than ever. Not only are the frontiers and contours of knowledge expanding and changing rapidly; in addition, college teachers now face a student body that is vastly more diverse in background and preparation. It is crucial that graduate education turn its attention much more fully to the task of preparing a new generation of college professors who can meet these challenges.

\title{
Only Connect: Politics and Literature 10 Years Later, 1982-92
}

\author{
Maureen Whitebrook, University of Sheffield
}

\begin{abstract}
The evidence available suggests that the method of using literature for teaching political science does work: the interesting questions are now those concerned with how the "method"the combination of politics and literature in political science teaching and research-may be systematised and disseminated for the benefit of the discipline of political science (Whitebrook 1983, 16).
\end{abstract}

That "now" was 1982-83. What I want to do ten years later is to show a somewhat paradoxical conjunction of a failure and a potential.

In 1982 I came to the United States on a semester's study leave with a research project derived in part from the literature search for my Ph.D. thesis and in part from my dissatisfaction with my own teaching program at that time. My intention was to survey the practice of teaching politics through literature at college level in the United States. The results of that research were written up in "Politics and Literature," an article that appeared in the APSA's News for Teachers of Political Science (Whitebrook 1983, 16-18).

Then $I$ argued for the teaching of politics through literature to be improved. Now I widen the argument: the discipline has moved on, to the point where the matter of what politics and literature has to offer the broader field of political theory must receive serious attention. The teaching of politics and literature continues, and it is increasingly well supported by a number of good publications. But the interesting questions have not been fully answeredsystematization has hardly happened, and there has been little benefit to the discipline as a whole from the continuing existence of a diffuse group of political scientists with a persistent interest in literary texts. But developments within that group taken in conjunction with the movements in political theory in the last decade are enough to indicate that what I advocated ten years ago is possible.

The response to my article in News for Teachers of Political Science was encouraging: more contacts and indications of what was being done across the United States, including the information that it had "inspired" a published work (Mallinckrodt 1987). And the eventual outcome of my visit and continuing contacts is the volume of collected papers, Reading Political Stories (Whitebrook 1992). So far, so good? Not so, I grudgingly respond. Ten years later-and reflecting on the 1991 APSA annual meeting-I want to return to the conclusion of that article, reconsider it, and try, again, to push onwards and outwards. 


\section{Failure?}

Despite some good work, which I discuss below, there is cause for concern among the political scientists who have persisted in their interest in connecting politics and literature and for the profession generally. Take, for example, APSA annual meeting sessions. The 1988 politics and literature program "was put together to reflect some of the diversity of interests that is apparent from the publications in the field"': Edith Wharton (changed by the paper-giver to popular fiction), science fiction, Macbeth, James Baldwin. (There has been a similar diversity of topics in the years before and since.) That program, apparently, represented a miscellany of approaches, methods, and underlying political viewpoints or philosophies (like most other politics and literature sessions that I have attended or reviewed). Thus, the methods involved included inquiring about literary work via politics-examining a single author's work (generally recognized as having some political connotations), using a political theory perspective as a critical tool; the close reading of a literary text, working from the literature to a "political" conclusion; taking literature-certain fictions-as so interrelated with politics to argue that the fictional form is necessary to political understanding; and presenting a political sociology of literature in respect of a certain genre.

In fact, the papers indicated that there had been movement. Close reading of a text to bring out a political point goes beyond the mere assertion that politics and literature are connected: close reading of literary texts is now frequent as a stimulus to thinking about politics, offering a link, specifically between political theory and political practice. The consideration of a writer's work from a political perspective not only provides a political reading of the work as such but also allows for consideration of a specific aspect of the politics-literature relationshipwhether or not the literary and the political treatment of certain themes are, or should be expected to be, consistent. Considering what works of fiction are useful for political reading directs attention to how fic- tions relate to political science-are they mirrors of the real? Taking a certain fictional genre as given allows for that body of texts to be brought into political science-so the literary text might serve a direct function for political science? And some distinct themes emerged across the papers: "tragedy" as a concept well treated in literary texts but relatively neglected in political theory; "selfconsciousness" as a common idea in literature and political theory; the relationship between thought and action explored in the literary mode. On the other hand, John Nelson's paper, "Science Fiction as Syzygy: Political Mythmaking for Post-

\section{Considering what works of fictions are useful for political reading directs attention to how fictions relate to political science -are they mirrors of the real?}

moderns" constituted an obvious case of what is likely to happen when the connections are attempted-at 158 pages of close argument it showed that such attempts are so suggestive that limiting the range of discussion to a single instance is very difficult. And although there were obvious connections to other programs of that meeting specifically concerned with postmodernism and political theory and political science, those connections were not madefrom either direction. At the 1989 annual meeting, the two politics and literature panels were more focused, on the United States and on Europe, but again the papers stood apart from discussions of similar topicsU.S. foreign policy, Max Weber, for example-elsewhere in the meeting.

To a large extent the heterogeneity of these recent APSA programs is very much a reflection of how things are in this relatively nonorganized branch of the discipline-more people are doing more work. But I am concerned that after a decade of effort there has been little advance, either within the subfield or between it and the discipline at large. The "failure" is the failure to move on: organizationally, there has been a failure to organize, so that it has taken much persistence (on the part of a few people) over the last ten years to establish (at last) an organized section on politics and literature in 1992. And, intellectually, there is the static state of much of the teaching, research, and writing of this period and a continuing failure to interact with the rest of the discipline let alone with the complementary discipline, literary studies; hence, typically, the persistence of the blanket title of "politics and literature."

The last decade has seen a vast amount of work in political theory that is at least potentially crossdisciplinary-so that it is odd that the section of the discipline avowedly interested in cross-disciplinary connections should fail to actually move towards helpful sources of support. The most obvious evidence for this failure is the continuing practice of taking the plots of novels and plays as unproblematic sources for political analysis-using literature in a way that is rightly criticized by the lit.erary specialists (and even by perceptive students). Too many of the practitioners in this field are still working with crude conceptions of "literature," equating novels or plays with realist narratives where plot is taken as an account that can be treated like a case study and ignoring style, structure, metaphor-all those aspects of narrative technique that the literary specialists have already recognized as potentially political in themselves (and many of which relate, as I have suggested, to issues already recognized as matters of concern to the discipline). The notes and references for most of the published work in this field show that political scientists persist in working in a cross-disciplinary area strictly within the confines of their own discipline-an odd procedure and not the case in other cross-disciplinary endeavors such as those that link politics and the environment or politics and biology.

\section{Potential?}

So far, so gloomy. But I remain convinced that work in this field has 
much to offer political science, and the evidence of the last ten years suggests that modest movement to date could be accelerated. The "potential" is the increased evidence of what might be done, both internally, from the work in politics and literature itself, and externally, from the possibility of connections with present work elsewhere in the discipline.

This has been a decade of effort within this subfield of the discipline, so that I can argue that there is now a sound basis for moving forward. The politics and literature group has done more than survive: thus, the networking represented by the Politics and Literature Newsletter, circulated to several hundred political scientists, the acceptance of politics and literature programs as regular features of regional and national APSA meetings, and the establishment of an organized section. In particular, there have been a number of major publications in this period: Ernest Yanarella and Lee Sigelman's edited collection, Political Mythology and Popular Fiction (Yanarella and Sigelman 1988), Ethan Fishman's Likely Stories (Fishman 1989), Catherine Zuckert's Natural Rights and the American Imagination (Zuckert 1990), and my edited collection Reading Political Stories (1992). These volumes have preceded (and somewhat encouraged) the suggestion that "politics and literature will be a growth area in the next ten years" a remark I heard more than once from publishers at the 1991 APSA annual meeting. And, more concretely, these books also represent the range and quality of work being produced.

However, that kind of internal evidence may be accounted self-serving for a small group within the discipline and is certainly not good enough to justify the claims I advance here. What is potentially much more significant is the need for connections at a more general level. Many of the themes and concepts presently of interest to political theory have obvious connections to literature, literary texts, and literary criticism and theory: questions of identity and the self and (multiple) selves, and community; cross-disciplinary work around the debatable issue of postmodernism; examination of modes of discourse; doubts about "rationality"; and tragedy. And much of the discussion in political theory around the shortcomings of liberal theory points very stronglyalbeit implicitly - to the need to bring literary sources into mainstream political theory. An example, by analogy, of what can be done exists in the present resurgence of work in law and literature. Narrative theory, narratology, draws on work from history, philosophy, literature-but not political science. (And postmodernism, emphasizing pluralism, openness, the deconstruction of texts, is everywhere.)

Political scientists who take literature seriously could make definite connections and contributions to major work in the social and political sciences. For example, major relevant and, for our purposes, supportive publications from Alasdair MacIntyre, Richard Rorty, and Charles Taylor remain undiscussed. MacIntyre's After Virtue includes a key chapter (Chapter 15), "The Virtues, the Unity of a Human Life and the Concept of a Tradition," which takes the notion of "narrative"' as central, and claims that "narrative history of a certain kind turns out to be the basic and essential genre for the characterisation of human action' (MacIntyre 1985,208 ). His concept is relatively undeveloped, and there has been no attempt from within political science to work out the implications of its inclusion within MacIntyre's own argument, or to link it to specific narratives-to the novel as typical narrative form, for instance.

Similarly, Ronald Beiner's Political Judgment (Beiner 1983) includes a section on "Storytelling and Narrative Truth," which notes Walter Benjamin's observation that the art of storytelling has atrophied and thereby effectively issues an invitation to recommence storytelling, a practice well understood by the politics and literature set. Both Richard Rorty (in Contingency, Irony and Solidarity) and Charles Taylor (in Sources of the Self) have recently used literary texts as part of their theoretical arguments; both have been criticized by reviewers for their handling of those texts. Political scientists who work with that kind of material are potentially well equipped to offer what is needed-what I have called "political literacy criticism," or better designated, perhaps, as "literary political criticism.,"

\section{The 1991 APSA Annual Meeting as Example of Problem and Potential}

I take the 1991 APSA annual meeting as a typical and useful example of the problem and the potential for politics and literature within political science (at least as represented by its professional association).

The politics and literature group offered a panel at this meeting on "The Literature of Oppressed Groups: Feminism"' (a title which of itself failed to relate well to the perceptions of feminist political theory and political science expressed elsewhere in the meeting) with two papers, "The Conflict Between Personal Commitment and Human Fulfillment in Kollontai's Love of Worker Bees" (Naomi Zauderer) and "The Literature of Human Reproduction: The Handmaid's Tale and Beyond" (Thomas Shevory). (A third scheduled paper on Virginia Woolf's Three Guineas was not delivered.)

In discussing these papers, I wanted to emphasize the considerations that form the basis of this paper: that the generic label of "politics and literature" is no longer sufficient as indication of what is to be done-not any connection but a question of what connection is to be made. Much work remains at a basic level of content analysis, but even at that stage it is possible-and indeed essential-to consider what is particular for politics in the literary text. Thus, there should be attention to matters such as characterization and narrative voice. That leads into a second stage, attention to form, the method of literary discourse, and to the theoretically fruitful consideration of how form working on content can advance political argument. That is, for these particular texts, I expected to be able to raise discussion about Kollontai's realism, Woolf's satire and irony, Atwood's naturalist treatment of a dystopia, 
and to ask what difference the form made to the perceived political content of each text-crudely, why fiction rather than journalism, pamphlet, or poetry or, in Woolf's case, why essay instead of fiction? Such considerations should both precede and speak to the more obvious matter of the political content of each text. And, of course, the title of the panel directed attention to such questions as to whether there was anything in common here except gender of author, and whether as such that contributed anything to a feminist politics or political theory; and, if exclusivity is to be avoided, what these contributions from women writers added to a general political understanding. And, by the time of this panel, late in the meeting, I wanted to ask specific questions related to other panels-for example, what did an analysis of these literary texts add to our knowledge of oppressed groups (as, for instance, related to the Walzer panel, which I discuss below).

The politics and literature panels were ill attended. The lack of official listing resulting from failure to achieve Organized Section status meant that there may have been a lack of awareness that these panels even existed. But, in any case, do they have any particular (thematic) drawing power for those political scientists who do find their way to the back of the annual meeting program? Is there any apparent relevance to matters of concern to the discipline as a whole? In panel after panel of the 1991 APSA meeting, I heard eminent members of the profession call for more understanding of the condition of the individual in one or other of the well-recognized dilemmas of late twentieth-century liberalism; but I did not hear, as the subject of a paper, comment from discussant, or intervention from the floor, any suggestion of the way in which literary texts offer just that understanding.

At the most general level, frequent reference to Foucault and to Nietzsche now entail use of the term "imagination." That has long been a suspect term in political science though central to discussions of literature and fiction; its usage in political theory is problematical and the literary political scientists have some- thing to offer here. Similarly "narrative" has become a regular term-so much so that paper-giver and discussant can engage in dispute as to each other's narrative strategies in order to validate their positions. Again, there are 10, 20,30 years or more of experience in studying the practice of narrative already in existence within the discipline. More specifically, several panels in the main program of the meeting included attention to identity and the self-topics of central concern to political theory at the present. For example, panel 1.14, “The Mirrors of Otherness: Postmodernism as Promise or Danger?" included Jane Flax's paper "Sexual Parts and PartObjects: Psychoanalytic Marxism and the Problem of Gender," which related self and otherness to narrative. And panel 2.10, "Intersections of Feminism, Marxism and Postmodernism" included Nancy Love's paper, "Am I That Performance," suggesting, inter alia, that gender might be viewed as performance, drawing on a postmodern notion of performance, thus requiring consideration of acting, and of "constituting ourselves as works of art."

One of the best attended panels of the meeting was the roundtable on the political philosophy of Michael Walzer. From beginning to end, this panel was highly suggestive in terms of the politics and literature connection. For example, Walzer suggested, with reference to a "real" case, recent events in Czechoslovakia, that it was possible to "know" that certain events and actions were "right," "what it is that moves them and what moves us to support them," and that the claim "don't tell us lies any more" can be "instinctively" supported. But this is debatable-was debated-and it could constitute the basis of a discussion on the extent to which fictional models might be preferable for theoretical purposes, allowing as they do understanding of and reflection on purpose and motive. Thus, for instance, the discussion around the issue of the state, membership, and excluded groups could have drawn on a range of literary treatments of exactly those problems under discussion, from Coriolanus to July's People, from Greek tragedy to feminist novels.
It was suggested that Walzer's conversational style, opening up subjects for discussion and taking "real cases" for reflection, in sum, a kind of "artistic interpretation" - or "telling stories" - was something like a combination of political theory and architecture. (Not political theory and literature?) How do we take a distance from society, understand marginalization? How do we make judgements about others, people in societies other than our own? (By reading novels?-literature "distances" in more ways than one.) The matter of understanding others entails, it would seem, accepting that a hegemonic culture tends to exclude -but this discussion then shares with the literary political scientist such understandings as the variety of stories that are told in any society, the importance of the storytellerwho does tell the story, indeed-and the capacity of the stories told by oppressed groups to offer alternative loci of integration and loyalty than that given by the "official" account (including that of mainstream political theory). And thus to the connections that could be made from this discussion to specific works of fiction that successfully depict marginality, justice and injustice, citizenship, justice and obligation, exclusionNostromo, The Princess Casamassima, The Handmaid's Tale, Sula.

That discussion of excluded groups can be related directly to the paper on Virginia Woolf submitted for the politics and literature panel. Walzer and his discussants were somewhat concerned with how excluded groups might be integrated into a given society; Woolf's essays in Three Guineas make it only too clear, at a relatively early stage of feminist writing, that some groups might not want to be integrated-a point made in the discussion by Iris Young. Indeed, the texts (if not the actual presentation and discussion) presented in the politics and literature panel all speak to the discussion between Walzer and Young centered on the question as to what oppressed groups do want. Crudely speaking, for women, inasmuch as they do represent an oppressed group, Kollontai suggests that they don't know, Woolf that they want (or should want) to with- 
draw from the society that oppresses them, and Atwood that that withdrawal might well be to the family, understood in terms of loving relationships. Even at the level of content, the overt "story" of a literary text, this indicates the viability of moving between theory and literature. What the literary example does is to extend the discussion, especially in terms of mediating between the polarities of the formal discussion; for real groups or individuals the problem is not one of choice but of coping with the situation as experienced. (The Coriolanian dilemma is simply that there is not, often, "a world elsewhere.")

Again, Walzer wanted to say not that we can do without the state, but that the state is bearable in that we do not have "to live in it" all the time: the world is full of boundaries, and we live in different parts of the (our) world differently. And hence to multiple selves, as series or set of overlapping relations, entailing different but overlapping feelings, loyalties, and relations to others. Here, as elsewhere, when "multiple selves" were assumed or asserted, what was not said and not discussed was the obvious problem that multiplicity is contained within a single life. What the politics and literature panels have often focused on-as in, for example, Timothy Fuller's paper on Macbeth in 1988, or Naomi Zauderer's paper on Kollontai's The Love of Worker Bees at this meeting-is just that point: the tensions and contradictions inherent in the conjunction of multiplicity and singularity within the external constraints of a specific social setting. Attention to that, and connection between the theoretical and literary discussions would draw together many of the themes of a panel such as this-questions of integration and coherence, how narrative works describe and effectively analyze what are still points at issue for formal political theory.

My point here is, to put it plainly, that there was little or no overlap of attendance between these panels and the politics and literature panel, little or no cross-referencing of material, but a high degree of coincidence of themes and concepts. It must be, at the least, uneconomical to allow this situation to continue.

\section{Conclusion}

To a large extent the basic premise that politics and literature can and should be connected has been accepted within the discipline. But given that acceptance, two questions follow-how should the connections be made, and to what end? The emphasis has hitherto been on content; it needs to extend to method and outcome. The work already being done indicates, as I have suggested, a wide range of texts and themes-APSA meeting programs in that sense offer a sample of what politics and what literature has occurred to political scientists as subject(s) for connection.

But, for those who do advocate and somewhat practice the connections of politics and literature, my concern is that they have not taken up my previous modest proposals about the need to ground this work in a proper combination of politics and literature, entailing a recognition of the relevance of literary criticism and theory to political theory in this context. The politics and literature set remain somewhat marginalized within the discipline. Many of the developments in political theory in the last decade should have entailed the centrality of this kind of work; but the discussions on postmodernism, foundationalism, and individualism versus communitarianism are carried on with no help from those theorists who have much to offer from their own preferred sources. The politics and literature set needs to become more self-consciously theoretical: within political theory to interact with the most interesting work in mainstream political theory, with feminist and postmodernist work; and then generally to suggest what political theory and literature can do together, taking up the mere hints that have recently been made but not yet widely recognized and certainly not fully worked out, that political theory as a mode of discourse has narrative connections.

My concern for what the politics and literature set of political scientists is missing is by now compounded by frustration at a continuing blinkered approach, which begins to look like self-indulgence, and irritation that we are failing the disci- pline by this intransigence. The worst of attitudes is that which keeps the political scientist-cum-literary critic where he or she started. I have admired those persons who have brought their own-or their wife's (and the genderism here is factual and deliberate)-interest in reading novels into their teaching and writing; but I do not admire the attitude that goes no further-that continues to select texts on the basis of personal preference for bed-time reading, and that does not see any need to support their work, as in other aspects of political science, with theoretical and/or empirical connections.

Furthermore, I believe that there is a responsibility inherent in having been privileged to recognize the politics and literature connections, a responsibility to bring those connections out of a closed group into regular discussions. The ad hoc and random collections of papers and courses that at present still largely represent politics and literature in the discipline need, as I have said, a framework: some systematization, both intellectual and organizational. Our work cannot be taken seriously if it remains the (quasi-nineteenth century) leisurely pursuit of "gentleman scholars"' (and hence peripheral to our mainstream interests as political theorists). Many of us have to start by reminding, or persuading, ourselves that we are not just indulging in bringing a hobby-reading novels, going to the theater-into our professional lives, but rather that we are engaging in a valid and indeed by now vital part of the formal study of politics.

The responsibility-or blame for failure to act-does not, though, lay entirely with the politics and literature set. The discipline as a whole needs to acknowledge that this is not a fringe activity. We can make a very strong argument for what (all) political scientists are missing if they don't read novels. Real Men Don't Read Fiction isn't an acceptable 1990s slogan. But even short of insisting on that, there is a need, in a period where multi- or cross-disciplinary endeavors are eminently respectable to allow for them in practice, by not supposing, for example, that the political analysis of a 
novel is necessarily any less serious than yet another analysis of a work of political theory. $\mathrm{X}$ on Faulkner may be just as fruitful for political insights as $\mathrm{X}$ on Tocqueville; and $\mathrm{Y}$ on Bellow may be more interesting (and therefore more productive of further thinking on the part of the reader) than A on Rawls or B on Nozick on Rawls-again.

\section{References}

Beiner, Ronald. 1983. Political Judgment. London: Methuen.

Fishman, Ethan. 1989. Likely Stories: Essays on Political Fiction and Contemporary American Literature. Gainesville, FL:
University Presses of Florida.

MacIntyre, Alasdair. 1985. After Virtue: $A$ Study in Moral Theory, 2nd (corrected) ed. London: Duckworth.

Mallinckrodt, Anita M. 1987. The Environmental Dialogue in the GDR: Literature, Church, Party and Interest Groups in Their Socio-Political Context: A Research Concept and Case Study. Lanham, MD: University Press of America.

Rorty, Richard. 1989. Contingency, Irony and Solidarity. Cambridge: Cambridge University Press.

Taylor, Charles. 1989. Sources of the Self: The Making of the Modern Identity. Cambridge: Cambridge University Press.

Whitebrook, M. F. 1983. "Politics and Literature." News for Teachers of Political Science, Fall.

Whitebrook, M. F., ed. 1992. Reading Political Stories: Representations of Politics in Novels and Pictures. Lanham, MD: Row- man and Littlefield.

Yanarella, Ernest J., and Lee Sigelman, eds. 1988. Political Mythology and Popular Fiction. New York: Greenwood Press.

Zuckert, Catherine H. 1990. Natural Right and the American Imagination: Political Philosophy in Novel Form. Savage, MD: Rowman and Littlefield.

\section{About the Author}

Maureen Whitebrook is honorary research fellow in the department of politics at the University of Sheffield, England. She has written widely on the connections between politics and literature. Her latest work is editing and contributing to Reading Political Stories: Representations of Politics in Novels and Pictures. She is now working on a booklength study of the significance of narrative for political theory.

Continued from page 240

Amado, Jorge. "Domination," from The Violent Land.

de Tocqueville, Alexis. "The Tyranny of the Majority," from Democracy in America (1854).

Emancipation Proclamation (1863) and excerpts from the 13th, 14th, and 15th Amendments to the U.S. Constitution.

Jackson, Shirley. "The Lottery," from The Lottery and Other Stories (1948).

King, Martin Luther. "Letter from Birmingham Jail," from Why We Can't Wait (1964).

Melville, Herman. "The Trial of Billy Budd," from Billy Budd, Chapters 19-22.

Olsen, Tillie. Selections from Silences (1968).

Piercy, Marge. "Right to Life." (current)

Rand, Ayn. Excerpt from The Fountainhead.

Excerpts from U.S. Supreme Court cases of Korematsu v. U.S. (1944) and Gobitis v. Minersville School District (1940).

C. To Serve or Not to Serve

Thoreau, Henry David. "On the Duty of Civil Disobedience."

Excerpts from U.S. Supreme Court case Seeger v. U.S. (1965).

Leguin, Ursula. "The Ones Who Walk Away from Omelas," from The Winds Twelve Quarters (1975), pp. 275-84.

Wilkinson, Francis. "The Gay Cadet," from The Village Voice (March 13, 1990).

Chapman, Bruce. "Politics and National Service: A Virus Attacks the Volunteer Sector," from National Service: Pro and Con (1986).

Part III: Opportunities for

Citizenship and Service

A. The School and the University

Barber, Benjamin. "The Civic Mission of the University," The Kettering Review (1989).

Barber, Benjamin. "What Our 47-Year-Olds Know," from The New York Times (1987).

Bloustein, Edward J. "Community Service: A New Requirement for the Educated Person," Commencement Address, May 1988.

Clinton, William J. "Address on National Service," Rutgers University, March 1, 1993.
Dewey, John. "The Democratic Conception in Education," from Democracy and Education.

Moffatt, Michael. "What College is Really Like" and "Community" from Coming of Age in New Jersey (1989).

Rosovsky, Henry. Selections from "University Governance," from The University: An Owner's Manual (1990).

D'Souza, Dinesh. "Illiberal Education,'” from The Atlantic (1991).

Morris, Michael. "Educating Citizens for a Multicultural Society, from Public Leadership Education: Skills for Democratic Citizenship (1990).

Stimpson, Catherine. "Meno's Boy: Hearing His Story-and His Sister's," from $A c a$ deme. (current)

B. Neighborhood and Nation

Addams, Jane. Twenty Years at Hull House (1910), selections.

Berger, Peter and Richard John Neuhaus. Selections from To Empower People: The Role of Mediating Structures in Public Policy (1977).

Evans, Sara and Harry Boyte. "The People Shall Rule," from Free Spaces (1986).

King, Martin Luther. "On Being a Good Neighbor,"' from Strength to Love (1963).

Milk, Harvey. "A City of Neighborhoods"

(1978).

Roosevelt, Franklin Delano. Speech Announcing the Civilian Conservation Corps (1933).

Schaar, John. "The Case for Patriotism," from Legitimacy in the Modern State (1981).

de Tocqueville, Alexis. "Public Association," from Democracy in America (1854).

C. The World

Barber, Benjamin. "Jihad vs. McWorld," The Atlantic (March 1992).

Barry, Wendell, "The Body and the Earth," from The Unsettling of America (1977).

Easterbrook, Gregg and Evan Eisenberg, "The State of the Earth," from The New Republic (1990).

Kennedy, John Fitzgerald. Speech Announcing the Peace Corps (1961).
Excerpts from the Rio Summit Declaration. Mother Teresa. Words to Love By, selections (1989).

The anthology will also include the following poems as epigraphs for each section: Anna Akhmatova, "Untitled poem," from You Will Hear Thunder; Bertholt Brecht, "An Apologia" and "Son of the Insufficiency of Human Endeavor"; Nina Cassian, "A Man"; Thomas Hood, "Song of the Shirt"; Langston Hughes, "Let America Be America Again"; Anne Sexton, "After Auschwitz"; Walt Whitman, "I Hear America Singing."

\section{About the Authors}

\section{Benjamin R. Barber}

Benjamin R. Barber holds the Walt Whitman Chair of Political Science at Rutgers University, where he is director of the Walt Whitman Center for the Culture and Politics of Democracy. With Patrick Watson, he wrote the prize-winning $\mathrm{CBC}$ / PBS ten-part television series "The Struggle for Democracy,' published by Little, Brown. His latest book is An Aristocracy of Everyone: The Politics of Education and the Future of America (Ballantine, 1992), to be published in France by Belin Publishers.

\section{Richard Battistoni}

Richard Battistoni is director, Civic Education and Community Service Program, Rutgers University.

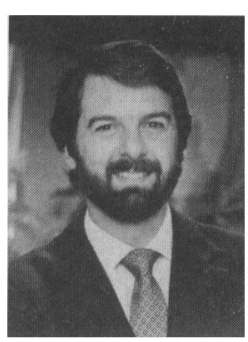

